\title{
Urban dimensions in rural development
}

\section{Alexander Schejtman}

United Nations Food

and Agriculture

Organization (FAO),

Santiago, Chile.
This article deals with the need to make some changes in the focus of policies for rural development and the relief of poverty. After noting the limitations of the traditional approaches taken by such policies, it is suggested (among other things) that the territorial dimension should be incorporated in their design, and the macroeconomic context and sectoral environment which condition those policies in the case of agriculture are reviewed, with emphasis on the structural heterogeneity of the sector and the existence of imperfect markets (section I). The article then deals with the limitations of traditional rural development approaches and the need to reconsider the role of rural-urban migrations (section II), after which it goes on to examine the links between urban issues and rural development, highlighting the need to take advantage of the potential for the establishment of suitable linkages between small urban communities and the surrounding agricultural areas (section III). Finally, it addresses some aspects relating to institutions and stresses the need for institutional innovations to make possible public-private participation and consensus-building at the local level (section IV). 


\section{I}

\section{The global and sectoral context}

We are currently witnessing a process of significant changes in the way the economies of the region operate. Deregulation of markets, liberalization of the external sector, privatization of public enterprises and fiscal adjustment have been accompanied in many countries by processes of decentralization of public management, the election of mayors and governors by popular vote and the delegation of areas of authority to municipalities, provinces or federal states, with growing transfers of resources and responsibilities to the local economies in the fields of education, health and even development. This therefore raises the need to review traditional rural development strategies in order to progress towards an approach of a more spatial nature in which the policy context takes into account the links between small and medium-sized urban communities and their surrounding agricultural and rural areas.

\section{The macroeconomic context}

At the domestic level, the structural adjustment policies applied with varying levels of intensity in all the countries are resulting in the redefinition of the rules which had governed the economies of the region for a number of decades in the past and to which the economic agents had become accustomed. The abandonment of protectionist practices and growing openness to external trade; the reduction of the relative weight of the public sector and the privatization of State-owned enterprises; the subordination of sectoral policies to the macroeconomic balances, and the bias towards the production of exportable goods, among other factors, are phenomena whose effects on economic growth, equity in income distribution and long-term sustainability are still hard to predict.

In the agricultural sector, the immediate result has been that the new conditions have been exploited mainly by the agricultural enterprises with the most suitable land for the production of exportable goods and the capacity to gain access to credit, technology and information on domestic and external market conditions, giving rise in a number of countries to a significant increase in exports, especially in non- traditional categories. While not denying the positive elements in these developments, this nevertheless represents a potential risk which should be avoided through suitable measures: the risk of accentuating the exclusive and polarizing nature characterizing the agricultural modernization process in the region in recent decades, which has been concentrated in certain products, certain regions, and medium-sized and large producers.

The changes in the international environment and in the domestic rules of the economies of the region mean that a sustained increase in competitiveness $^{1}$ and its corollary, the broad dissemination of technical progress, have become a necessary condition for growth and indeed for the very viability of production units. In the case of the agricultural sector of the countries of the region, these challenges have arisen in a special context with regard to agrarian structures and the operation of rural markets.

\section{The sectoral context: heterogeneity, imperfect markets and transaction costs}

There are two main structural factors which determine the functioning of the agricultural sector in the great majority of the countries of the region: the heterogeneity of their structure of production and the presence of flaws in the credit, insurance, technology, information, labour and other markets, or even the absence of such markets.

One of the features which is shared by the great majority of the countries and which derives from the period of transition from the hacienda to capitalist agricultural enterprises is the coexistence of business or capitalist agriculture alongside peasant agriculture. Because of the characteristics to which we shall refer later, this raises complex problems for the design of policies to provide incentives and promote the dissemination of technical progress, which is a necessary condition for competitiveness. Whereas in

\footnotetext{
${ }^{1}$ In simple terms, and in the case of small producers and rural workers with little or no land, being "competitive" means improving to some extent the levels of net income derived from the sum total of their activities.
} 
homogeneous structures a given incentive or a valid technological option (that is to say, in keeping with the relative resource endowments of producers) is effective for the great majority of the production units, in bimodal structures an incentive or technological option which is considered appropriate for large-scale modern business agriculture will probably not be suitable for the family agriculture sector in the context of a given set of relative prices.

\section{a) Contrasts in the internal operating rationale}

Even at the risk of repeating well-known facts, it is important to note that both the empirical evidence and a considerable theoretical base give grounds for maintaining that there are marked differences between what we have called the internal operating rationales or criteria used by the two types of agriculture to make decisions on what, how much, how and why to produce goods, and these are very important for the design of strategies or policies that aim to influence the behaviour and development of the sector.

The differences between the behaviour of the two types of organization are summarized in table $1,{ }^{2}$ and although this is not the place to embark on an analysis of each of them, it is worth noting the contrasts in the nature of the labour force and in the way of internalizing risks, because they directly affect the multiactivity patterns typical of peasant family units.

The fact that there is a non-transferable margin of labour in family agriculture (work by the children, the wife, or other unpaid family members, or "free" time of the head of household) means that this margin is only capable of creating value within that structure -that is to say, there is no other space in which this available working time can be profitably usedwhereas business agriculture, in contrast, depends on paid labour hired in the market. ${ }^{3}$

Risk considerations are also incorporated differently in the operating criteria, since whereas for an entrepreneur it is reasonable to adopt a higher-risk option if it is offset by higher profits, small producers tend to avoid options with a higher element of risk, no matter how much greater the income from a favourable outcome might be, because of the threat to their sustainability as families and producers that an adverse result would entail. ${ }^{4}$

These contrasts in operating rationales mean that policies designed to bring about given forms of behaviour on the part of the two types of producers cannot be identical and, hence, specific differentiated designs are required for each sector. Thus, for example, to take a simple example, a predictable set of the main macroeconomic prices (interest rate, exchange rate, wage levels), together with measures to moderate possible undesired effects of them, may be sufficient to determine the behaviour of modern business agriculture, but in order to bring about given changes in small-scale agriculture a more complex set of measures will be required which go beyond mere adjustments to the effects of macro prices.

As a result of the changes which have taken place in the rules governing the functioning of the economies of the region and the foregoing considerations regarding sectoral heterogeneity, two types of challenges arise for the two types of agriculture, involving different strategies and policies. Firstly, there is the challenge facing business agriculture, which runs the risk of suffering the erosion of its competitiveness if it is not capable of incorporating technical progress into the most critical links of its production chains, since the advantages deriving from labour costs and the natural resources endowment are losing part of their importance as sources of competitiveness. Secondly, there is the challenge of formulating options for the heterogeneous peasant sector (small farmers and rural families with little or no land), some of whose members run the risk of losing their status of producers, while others (the majority) are in danger of further increasing the extent and seriousness of rural and urban poverty unless they can incorporate processes that improve the employment options of their labour force; this must be achieved through policies which are differentiated according to

\footnotetext{
${ }^{2}$ For a description of the theoretical basis for our assertions, see Schejtman (1980) and Figueroa (1981).

${ }^{3}$ In another study, we noted that this situation makes it possible, under certain conditions and with respect to certain products which are labour-intensive and do not involve economies of scale, for these units to be potentially competitive with those that depend exclusively or mainly on paid labour (Schejtman, 1998).
}

\footnotetext{
${ }^{4}$ Lipton (1968, p. 335) asserts that while a prosperous American farmer may prefer a $50 \%$ chance of earning either US\$5,000 or US\$ 10,000 to the certainty of earning US $\$ 7,000$, an Indian peasant faced with the probability of earning 1,000 rupees as against the certainty of earning 700 rupees that barely allow him to feed his family nevertheless cannot put $x$ much below 700 .
} 
TABLE 1

Differences between the features of peasant and business agriculture

\begin{tabular}{|c|c|c|}
\hline Aspect & Peasant agriculture & Business agriculture \\
\hline Objective of production & $\begin{array}{l}\text { Reproduction of the family and of the } \\
\text { production unit }\end{array}$ & $\begin{array}{l}\text { Maximization of profits and capital } \\
\text { accumulation }\end{array}$ \\
\hline Origin of labour force & $\begin{array}{l}\text { Basically the family, with occasional mutual } \\
\text { exchanges with other units; exceptionally, } \\
\text { wage labour in marginal amounts }\end{array}$ & Wage labour \\
\hline $\begin{array}{l}\text { Employment commitment of the } \\
\text { head with the labour force }\end{array}$ & Absolute & Non-existent, except when legally obliged \\
\hline Technology & $\begin{array}{l}\text { Intensive use of labour, low density of } \\
\text { "capital" and purchased inputs per day } \\
\text { of work }\end{array}$ & $\begin{array}{l}\text { Higher capital density per asset and } \\
\text { higher proportion of purchased inputs } \\
\text { in the value of the final product }\end{array}$ \\
\hline Destination of product and origin of inputs & Partly the market & The market \\
\hline Criterion regarding increase in labour & $\begin{array}{l}\text { Maximum total product, even at the cost } \\
\text { of a lower average product. Limit: zero } \\
\text { marginal product }\end{array}$ & $\begin{array}{l}\text { Marginal productivity higher than wage } \\
\text { paid }\end{array}$ \\
\hline Risk and uncertainty & $\begin{array}{l}\text { Non-probabilistic avoidance: survival } \\
\text { algorithm }\end{array}$ & $\begin{array}{l}\text { Probabilistic internalization, seeking } \\
\text { profit rates proportional to the risk }\end{array}$ \\
\hline Nature of the labour force & $\begin{array}{l}\text { Non-transferable or marginal value of } \\
\text { labour }\end{array}$ & $\begin{array}{l}\text { Uses only transferable labour, in the light } \\
\text { of their skills }\end{array}$ \\
\hline Components of net income or product & $\begin{array}{l}\text { Indivisible family product or income, } \\
\text { partly in kind }\end{array}$ & $\begin{array}{l}\text { Wages, rents and profits, exclusively } \\
\text { monetary }\end{array}$ \\
\hline
\end{tabular}

Source: Schejtman, 1980.

the type of units concerned, on the basis of classifications of producers (or family units) which not only take account of this heterogeneity but are also functional to policy design and implementation. This functionality means that the classification criteria must include elements concerning the way these units fit into the economy, while the total number of categories must not exceed the management capacity of the public authorities. ${ }^{5}$

\section{b) Rural markets}

Agricultural activity in general and that of small producers in particular takes place in an environment in which the behaviour of the credit, insurance, technology, information and labour markets -as noted by Sadoulet and de Janvry (1995, p. 254)- is far from that of a "standard Walrasian economy" which assumes that all markets do exist, including the credit

\footnotetext{
${ }^{5}$ For some ideas on the design and implementation of differentiated rural development policies, which we do not have the space to analyse in detail in this article, see ECLAC (1982), de Janvry, Gordillo and Sadoulet (1997) and FAO (1997).
}

and risk markets, and that the equilibrium prices determined by these markets apply equally to all participants. In the less developed countries there are many market flaws, either because the markets do not exist or because the transaction costs ${ }^{6}$ associated with access to them are so high that it is more advantageous to the agents to effect transactions through institutional arrangements other than those of the market. This characteristic gives rise to forms of institutions and inter-agent relations with special features which distinguish them from the more formal institutional mechanisms in the markets in question. As noted later in this article, the generation of different forms of linkages between small producers and other agents is often a response to the absence or inefficiency of one or more markets.

An example of this is the obstacles faced by small producers who have potential resources for growing crops of higher value.

\footnotetext{
${ }^{6}$ We will deal with the concept of transaction costs later.
} 
i) Credit. While basic grains can be cultivated with amounts of inputs which are in keeping with the financial resources of peasant families, commercial crops almost always demand outlays on inputs and even on additional labour which are far beyond the possibilities of the units and represent a formidable barrier to progressing to products of higher value, ${ }^{7}$ even though the activity in question may amply justify the credit needed.

ii) Insurance. As already noted, small producers internalize risks in a manner which is different from that typical of medium-sized and large enterprises. They need formulas which reduce the risks involved in embarking on the production of non-traditional crops, since these involve higher direct costs, are more susceptible to factors that affect quality or yields and to greater price fluctuations, and are also of no direct use for family consumption. As they do not have the capacity to insure against them, small producers often result to various mechanisms to face the risks involved, such as the sale of assets (livestock), the renting out of their land, diversification of crops, the cultivation of crops which are less subject to fluctuations although they give less income, work away from the farm, emigration, and agreements with buyers.

iii) Information. Access to information on technological options, the types of products for which there is a demand and the corresponding quality requirements and prices, alternative intermediation channels, restrictions on the use of certain inputs, etc., is increasingly important for determining the success of an activity. Normally, only the segment made up of modern producers possesses this information, which is in the hands of the agroindustrial enterprises. The segmented nature of the information markets means that this information only reaches small producers through buyers or intermediaries, since the cost of acquiring it is beyond their possibilities and is even beyond those of their cooperatives.

iv) Specialized technology and inputs. The market for a number of the inputs or services used in the production of non-traditional crops is generally too narrow, so that, for small producers, access to it can only be gained through some form of agreement or association with agroindustry or agro-trade. This is so, for example, in the case of new seed or plant varieties, changing requirements with regard to agri-

\footnotetext{
${ }^{7}$ The costs per hectare of many non-traditional crops may be 10
} or more times greater than those of basic grains. cultural chemicals, or new storage and packaging techniques.

v) Land. The land market continues to be too rigid to adjust supply and demand; for a long time it was subject to legal restrictions, even in countries which did not carry out major agrarian reform processes. In recent years, these restrictions have tended to be relaxed with the explicit intention of promoting the development of that market, but its dynamism has been influenced more by speculative considerations than by the value of land as a production resource. In the case of small farms which their owners are reluctant to sell or rent, mechanisms which take the place of sale or rental have arisen in order to make possible the initiation or expansion of some particular form of activity, such as the various types of contract agriculture. $^{8}$

vi) Labour. The labour market in rural areas has special features deriving from the multi-active nature of small producers, which permits the payment of lower wages for similar activities than those paid in urban areas; the isolation or dispersion of rural workers with respect to means of transport, which limits their mobility; the seasonal nature of agricultural activities, which, because of the need for flexibility, impedes the expansion of permanent jobs; certain forms of intermediation (advances) which reduce the transparency of the remuneration received, and the lack of information on available opportunities, among other factors. ${ }^{9}$

With regard to market flaws, a recent document by the FAO (1997), as well as examining the implications for agriculture of the changes in the macroeconomic environment, proposes some sectoral policy options compatible with the market and transitional mechanisms for bringing them into effect, such as price bands, export promotion, transfers of income to small producers (instead of production subsidies), or the promotion of contract agriculture, as responses to one or more of the market problems described.

\section{c) Transaction costs}

Transaction costs are those which an agent has to pay, over and above the price of the good or service he is acquiring, in order to try to ensure that it corre-

\footnotetext{
${ }^{8}$ See, in this respect, Schejtman, 1998. Another of the consequences of the rigidities observed in this market is that they limit the scope of processes of market-based redistribution in favor of small producers, such as those initiated in Brazil and Colombia. ${ }^{9}$ For a more detailed analysis of these markets, see Figueroa, 1998, pp. 96-104.
} 
sponds to his expectations; thus, they include the costs of searching, information and supervision, and ensuring fulfilment. According to Sadoulet and de Janvry (1995, pp. 255-256), if trade exchanges involve incentives for opportunistic behaviour by the parties which may result in adverse selection or moral hazard, avoiding them entails high costs. The first of these involves ex ante costs of preselecting candidates, while the second involves ex post costs for follow-up, legal action and measures to secure fulfilment.

On the one hand, market flaws and their effects on transaction costs are phenomena exogenous to the family unit, which may be seen as structural barriers to their access to certain markets; on the other hand, they become endogenous determinants of choices between sale and home consumption or between outside employment and self-employment when there is a gap - generated by transaction costs- which means that the cost of buying something exceeds its sale price or that net productivity exceeds the remuneration plus transaction costs of seeking employment away from the farm. ${ }^{10}$ Likewise, it may be that a farmer opts for informal credit instead of a bank loan, even though the latter may be available at a lower rate of interest, if the transaction costs of obtaining credit from a bank, plus the interest rate, exceed the cost of informal credit.

According to Benedicty, ${ }^{11}$ the price gap can be narrowed by reducing the specific transaction costs facing the unit. If this assumption is true, we must immediately acknowledge that we know very little about the structure of transaction costs. We must also acknowledge that the conventional approach -that is, models positing a structure of effective interest rates, land rents and wages that only vary as a function of the size of the farm- is based at best on purely abstract approximations. An urgent effort is needed to collect information at the level of the family unit on the structure and determinants of transaction costs: undoubtedly quite a challenge.

Market flaws or transaction costs give rise to "linked transactions" which make it possible to get round these problems through exchanges in which access to a product, a service, employment or some form of insurance becomes part of a single broader operation, ${ }^{12}$ in clear contrast with the anonymous and systemic interdependence of economic activity (in the respective competitive markets) posited by general equilibrium theory (Bardhan, 1991, p. 237).

Although there may be a clear awareness, in very generic terms, of the existence of market and government failures which result in transaction costs for family farms, when they actually occur they have special local features, so that their detection and possible solution must be approached at this level. General formulas are just guidelines for focussing the areas of observation: in contrast, only the local-level analysis of the nature and specific magnitude of their effects can serve as a reliable guide for action.

\section{II}

\section{Traditional rural development approaches}

\section{The main limitations}

If we understand rural development policies or strategies as being a set of actions designed to improve the living and working conditions of the rural population, and especially of small producers and labourers with little or no land of their own, we can see that the

\footnotetext{
${ }^{10}$ This is not the place to analyse in detail the theoretical bases for these assertions. See, in this respect, Sadoulet and de Janvry, 1995, pp. 149-159.

${ }^{11}$ In a comment by M. de Benedicty on an earlier version of this paper.
}

traditional approaches taken by such strategies suffer from a number of limitations, as noted below.

i) They take no account of the high degree of heterogeneity which is characteristic of small-scale

\footnotetext{
12 The absence or imperfect nature of certain markets for small producers is often "solved" through complex arrangements between agents, as in tomato production in the Ica Valley of Peru, where agroindustries rent land from the peasants, who then work it on behalf of the enterprise. For the peasants, the wages paid make up for the lack of credit for growing crops, which, together with the lack of access to technology and insurance, prevents them from growing tomatoes on their own account, while for the enterprises this conditional form of rental makes it possible to overcome the rigidities of the land and labour markets (ECLAC, 1996b).
} 
agriculture and, hence, of the need for policies differentiated according to the type of producer, which have only recently, and in a very partial manner, begun to be adopted explicitly by some countries of the region.

ii) They are centered on agricultural activity, without taking account of the multi-active nature of the family units, despite the importance of work away from the farm for the functioning of the agricultural activity itself, as an important source of supplementary income and a part of the mechanisms for coping with the risks inherent in agricultural production, ${ }^{13}$ and in particular they fail to take account of the importance that non-agricultural rural employment has been assuming (a matter which we will deal with later).

iii) They do not take action, or do so only in a fragmentary or sporadic manner, to correct (or rather to make up for, not always successfully) the market flaws or total absence of markets which are frequent among small producers (with regard to information, technology, inputs and products, and secure credit).

iv) Except in a few cases, they do not consider agricultural production in the context of its linkages with other agents in the primary productionagroindustrial processing-marketing chain, thus wasting (among other things) the opportunity to induce agroindustry to play the role of an agent for the spread of technology to particular segments of the small farming sector. ${ }^{14}$

v) At the local government level, they are unable to adapt the centrally formulated strategic proposals or policies to the specific potential and limitations of each local area.

vi) In a broader sense, they do not take account of the potential effects on changing agricultural pro-

\footnotetext{
13 In a study on Ecuador it was estimated that income from sources other than agricultural production accounted for between $80 \%$ of total income, in the case of peasants with less than one hectare of land, and $30 \%$ in the case of those with between 5 and 20 hectares (de Janvry and Glikman, 1991), while in another study, on Mexico, it was estimated that off-farm income accounted for an average of $36 \%$ of the total, ranging from $58 \%$ for peasants with less than 2 hectares to $24 \%$ for those with over 18 hectares (de Janvry, Gordillo and Sadoulet, 1997).

${ }^{14} \mathrm{See}$, in this respect, the series of studies on Agroindustry and Changing Production Patterns in Small-scale Agriculture which were prepared under the ECLAC/FAO/GTZ agreement for a number of countries of the region and which are summarized in Schejtman (1998) and ECLAC (1996a).
}

duction patterns and the living and working conditions of the rural population that can be achieved through the development of particular forms of linkages with the urban communities with which small producers and rural dwellers interact. ${ }^{15}$ Exceptions to this are the recent studies by Paniagua (1994 and 1997) on Bolivia and Peru, respectively, and by Riordan (1997) on Peru, which bring out the potential of an approach of this type for rural development and the relief of poverty.

\section{Migration and rural development}

One of the explicit or implicit objectives of rural development has often been "to avoid rural-urban migration" on grounds that, in the most highly ideologized versions, idealize the rural environment in contrast to the satanic urban world, while the other objectives are based on social cost and benefit considerations.

The processes of hyper-urbanization which have marked most of the countries of the region since the 1950s may perhaps have justified the anti-migration bias of many rural development proposals, but this has not prevented the changes in spatial population distribution -with a decrease in the relative weight of the rural and agricultural population- from continuing to follow a "natural" tendency which only coercive measures or costly conservative policies can prevent. ${ }^{16}$ If we admit that rural-urban migration is going to continue, then the central question is: what type of incentives need to be generated in order to redirect these migratory flows along a course which is more favourable to rural development?

\footnotetext{
${ }^{15}$ Even the so-called integral rural development strategies have been restricted to the activities of small producers as agricultural workers and to the linkages they have with their environment in that limited capacity; although the studies on "survival strategies" do take some account of urban activities when analysing employment and income options, their examination of the potential of such linkages is confined to that restricted field.

${ }^{16}$ Generally speaking, a significant part of the "agrarian" movement, in both its most populist or peasant-oriented versions and those of a more developmentalist nature, implicitly or explicitly justified its proposals (at least in part) as being designed to check rural-urban migration, refusing to acknowledge that "migration from rural areas is one of the basic elements of economic development: it is necessary, obligatory and positive. If the surplus population did not emigrate from rural areas it would be impossible to embark on the modernization process..." (Vergara, 1992, p. 184).
} 
In this connection, it is worth mentioning -albeit very briefly- some of the positive effects that such migration can have on rural development, because of its potential direct or indirect contribution to family income, changing production patterns in small-scale agriculture, and the solution of problems of poverty and environmental deterioration:

i) With regard to income, those who migrate generally do so in search of better income opportunities than those offered by agricultural activities: in this sense, the frequent assertion that migrants end up by swelling the mass of urban unemployed does not appear to be empirically justified, as details regarding a number of Latin American cities show. ${ }^{17}$

ii) With regard to changing production patterns, migration aids the agricultural modernization process in various ways. Firstly, because (other things being equal) it raises the productivity of those who remain by improving the ratio of land area per active person (provided that those who migrate do not consist of the most productive elements, leaving behind only children and old people), and in some circumstances it can improve resource allocation. Secondly, because -as shown by many examples of changes in smallscale agriculture- it is often the migrants who induce such changes by bringing information and ideas that can only be acquired in the urban environment. Thirdly, because -especially in areas where the holdings are very small and the possibilities of making more intensive use of labour are very limited- migration may be a necessary condition for continued survival and may help to subsidize agricultural activities with income earned away from the farm. Fourthly, off-farm income may help to solve (or at least reduce) the difficulties that small producers have in adopting the innovations that are open to them because of the lack of a surplus to cover the cost and the impossibility of taking the risks that all innovation involves.

iii) With regard to poverty, it may be noted that in almost all the countries of the region there is usually a close correlation between the degree of rurality of a given administrative area or locality and the level of poverty in it; moreover, family sizes and rates of dependency are higher in rural than in urban areas, and there is also a bigger gap between actual and desired fertility, as the relevant studies show. ${ }^{18}$

iv) With regard to environmental problems, it is a well known fact that the higher the ratio of inhabitants to land area, the greater the tendency to make intensive use of steeply sloping land, to deforest marginal areas, and to intensify the cultivation of rain-fed areas, resulting in various types of environmental deterioration. On the other hand, migrations to the big cities also give rise to environmental problems. Estimates by Jeffrey and others (1989) indicate that $80 \%$ of the Latin American poor live in urban or rural areas of high ecological vulnerability, and $24 \%$ live in urban areas. ${ }^{19}$

In the light of these considerations with regard to migration, rural development and poverty, it is clear that the latter two aspects need to be dealt with in a broader context than that provided by a strictly agricultural or purely rural framework.
${ }^{17}$ Estimates made in the late 1960s indicate that in Lima and various cities of Colombia the unemployment rate among migrants was quite low: lower, in fact, than among non-migrants. In Santiago, Chile, the rate of unemployment among male migrants was $4.6 \%$, while it was $7.2 \%$ among the established urban population. In Mexico City, even though few migrants had arranged employment before migrating, $46 \%$ found work within a week, a further $30 \%$ found jobs within a month, and two-thirds of the total gained substantially in terms of income.

\footnotetext{
${ }^{18}$ A number of population and health surveys made in various countries show that: "the level of fertility desired by families is almost $40 \%$ lower than their effective fertility..."; the lower the economic and social level of the family, the greater the gap between their effective and desired levels of fertility, which indicates, on the one hand, that there is a by no means negligible margin for reducing the further growth of poverty and, on the other, there is a need to design more efficient methods of information than those currently used, in order to bring effective fertility closer to the desired level. Furthermore, $80 \%$ of adolescent mothers in urban areas and $70 \%$ in rural areas belong to the poorest 50\% of households (ECLAC, 1998, pp. 114-125).

${ }^{19}$ For a critical view of the effects of migration, which stresses its effects on the inter-family income distribution in an area and is in opposition to the views presented here, see Lipton, 1980, pp. 1-24.
} 


\section{III}

\section{The urban dimension and rural development}

The classic paradigm on the role of agriculture in development processes (as set forth by Johnston and Mellor, for example) centered on the expected contribution of agriculture to development in general and urban-industrial development in particular, stressing that this included the transfer from rural to urban areas of savings, labour force, food, foreign exchange, etc. However, the opposite question has rarely been asked: what contribution could or should urban development make to agricultural development? At this point in time, it seems desirable to note that on the one hand the disparity between the development of the big cities and rural areas, no matter how it is defined, is extremely serious and shows no signs of diminishing, while on the other hand the rapid increase in urban-rural linkages is beginning to blur the limits between them (Da Silva, 1998).

This prolonged failure to take any account, in policy formulation, of the role that urban areas could play in the development of rural areas occurred even though studies on economic or agrarian history, when dealing with the links between the formation and development of urban-industrial areas and agricultural development, highlighted the fact that in countries of early or late industrialization which had relatively homogeneous agricultural structures there were virtuous circles of reciprocal demand between agriculture and industry in the initial phases of industrialization. At the beginning, there was a demand for simple consumer and producer goods on the part of a relatively homogeneous mass of small and medium-sized agricultural producers, which led to the appearance of domestic manufacturing enterprises to satisfy that need, but the development of the latter enterprises generated, in turn, a growing demand for food and agricultural inputs, giving rise to increasingly sophisticated consumption patterns and production techniques and, last but not least, the emergence of an extensive range of entrepreneurs (Jones and Woolf, 1969).

This growth pattern contrasts, in every one of its aspects, with that displayed by societies where, at the beginning of their industrialization processes, the countryside was dominated by the hacienda or plantation system, because of the effects of the latter on the distribution of power, accumulation patterns, the bias in their paths of technological change, and the limitations faced in the generation of a critical mass of entrepreneurial capacity (Schejtman, 1997, p. 127).

The studies by Hirschman (1961) on forward and backward linkages and by Myrdal (1962) on circular causalities are essential sources for analysing the links between urban development and its surrounding rural environment, while the proposal by Evans (1992) of a model for a "virtuous circle" of urbanrural development is a micro-level replica of the process in question. Despite its qualities, however, the main weakness of this proposal is that it does not take into account the fact that this process does not start from zero or in a context of homogeneous agrarian structures but, on the contrary, takes place in a context of highly differentiated production and social structures.

Another neglected aspect, linked with the foregoing, has been that of the space or territory in which economic activity is carried on. As Krugman (1997, p. viii) notes, although this is a matter of obvious practical importance it has been completely absent from the standard corpus of economic theory and, we may add, from our own studies too. ${ }^{20}$ The same author (ibid., p. 41) notes that spatial models of economic activity (which had their origin in Von Thünen's studies at the beginning of the last century aimed at explaining the formation of land rents as a function of distance from an urban area), as well as Christaller's studies at the beginning of the present century on "central places", aimed at analysing the location of manufacturing activities and markets with respect to a given homogeneous agricultural population, went unnoticed in the mainstream economic literature until well into the 1950s. Their influence on economic geography and "regional science" is undeniable, however, and was rescued by Krugman in what has come to be called the "new economic geography" (Renkow, 1998).

\footnotetext{
${ }^{20}$ Carlos Franco reproached researchers on rural problems for the small number of studies designed to link the agrarian question with migration, urbanization, micro-regions and the urban informal sector (Franco, 1992, p. 395).
} 


\section{Urban development and rural change}

In recent years, a debate has been growing up in "regional science" circles on the functional integration proposal, versus the location-allocation proposal, centered basically on the development of methods for determining the location of services and infrastructure in urban areas that can serve as inductors of rural development. Although this is not the place to go into these proposals in detail, ${ }^{21}$ we may note that while the latter proposal takes actual or potential demand as its main criterion and does not take account of the problems deriving from unequal distribution of income, the first of these proposals seeks to generate linkages from the urban area to its surrounding rural environment through the supply of services and infrastructure, starting from the assumption that in most developing countries the problems of polarized spatial development were the result of skews in the distribution of national investment, so that their solution would call for corresponding skews in favour of secondary urban areas (Rondinelli, quoted by Hansen, 1990).

The functional integration approach comes closer to tackling the problem of strengthening the positive linkages between small urban communities and the surrounding rural areas, but unless it takes account of the heterogeneity of the agricultural production structure this approach does not ensure that its benefits will be accessible to small producers, unless the characteristics of the services and infrastructure are defined in the light of the restrictions or needs that affect those producers. This is noted, for example, by Johnston and Kilby (1975) in their excellent study on agriculture and structural change, which explores the contrasts between the forms of development based on bimodal and unimodal agricultural structures.

There is broad agreement among different analysts, however, that the strengthening of urban-industrial areas benefits agricultural development. They note that the cities have been an important source of generation and dissemination of agricultural technology (Jacobs, 1970); that the capital, inputs, labour and product markets tend to be less imperfect in the urban-industrial environment, and that, as a spillover effect, neighbouring agricultural areas can enjoy greater

${ }^{21}$ See, in this respect, the series of articles that appeared in International Regional Science Review (1992a and b) and also Belsky and Karaska, 1990, pp. 225-240. mechanization, less surplus labour, better prices for their products and, ultimately, better remuneration for their work (Schultz, 1953; Katzman, 1974).

According to Schultz, i) economic development (usually) takes place in a specific location matrix, and there can be one or more such matrices in a particular economy; ii) those location matrices are primarily of an urban-industrial nature, as centres where economic development originates, and not normally of a rural or agricultural nature, even though some agricultural areas are better placed than others with respect to those centres; and iii) the existing economic organization works better at the centre of the development matrix or close to it, or in those agricultural areas more favourably located with respect to that centre; it does not work as well in areas located on the periphery of the matrix (cited by Bhadra and Salazar Brandao, 1993).

In an estimate made for the state of São Paulo of the correlation between per capita added value in manufacturing and certain changes in the agricultural structure, it was found in two periods that there was a positive correlation with the percentage of arable land used, the number of tractors and pickup trucks, the use of fertilizers and pesticides per hectare, the density of machinery per worker, and the output per hectare and per worker; in contrast, the correlation with the amount of land per worker was negative or neutral (i.e., this does not appear to affect the degree of concentration).

For his part, Vergara (1992, p. 190) demonstrates the link between rurality and agricultural modernization for Peru, in a classification of communes into different strata (see table 2).

\section{Non-agricultural rural employment}

\section{a) Its size and importance}

To the best of our knowledge, the first study seeking to explore the size and characteristics of nonagricultural rural employment (NARE) ${ }^{22}$ in Latin America is that prepared by Klein (1992) for the Regional Employment Programme for Latin America and the Caribbean (PREALC) of the International Labour Organisation (ILO). This study shows that in

\footnotetext{
22 Non-agricultural rural employment is that involving rural residents who work in activities other than agriculture (commerce, construction, industry, services, etc.), while urban agricultural employment is that involving urban residents working in agricultural activities in the surrounding rural area.
} 
TABLE 2

Peru: Urbanization and agricultural modernization, 1972

\begin{tabular}{lcccc}
\hline & $\begin{array}{c}\text { Hectares } \\
\text { per capita }\end{array}$ & $\begin{array}{c}\text { Mechanization } \\
\%\end{array}$ & $\begin{array}{c}\text { Fertilizer use } \\
\%\end{array}$ & $\begin{array}{c}\text { Agricultural } \\
\text { EAP, } \%\end{array}$ \\
\hline Stratum I & 0.52 & 1 & 11 & 77 \\
Stratum II & 0.77 & 4 & 16 & 64 \\
Stratum III & 1.13 & 21 & 36 & 35 \\
Stratum IV & 1.83 & 46 & 32 & 65 \\
\hline
\end{tabular}

Source: Vergara, 1992.

FIGURE 1

Growth rates of rural employment

in Latin America in the mid-1980s

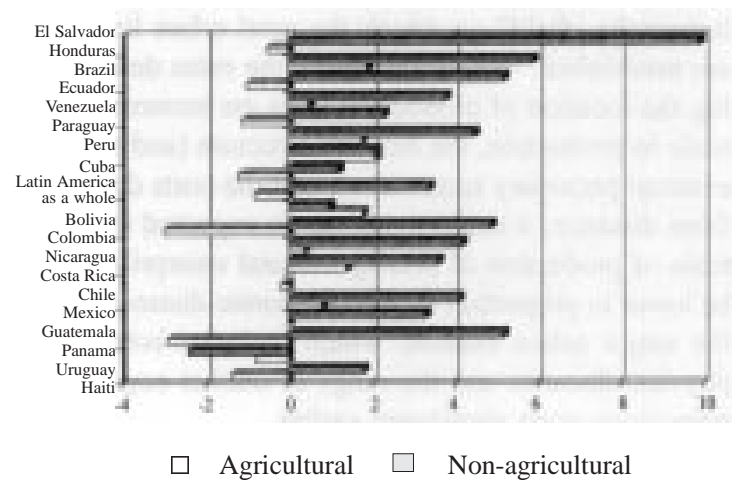

Source: Klein, 1992.

the 1980s, in almost all the countries, NARE grew significantly faster $(3.4 \%$ per year) than agricultural employment $(0.8 \%$ per year), that is to say, even faster than the growth rate of the economically active population of the region. Klein also notes (ibid., p. 2) that in 12 of the 18 countries for which information is available NARE increased more rapidly than total employment, and in eight countries it even grew faster than urban employment ${ }^{23}$ (figure 1). As regards the structure of NARE, Klein notes that it is similar to that of the urban non-agricultural labour market in terms of the relative shares of each sector of activity (ibid., p. 7).

More recent data on various countries confirm these trends in the region: Da Silva (1998, p. 19) notes that in the period from 1992 to 1995 the rural

\footnotetext{
${ }^{23}$ Except in Bolivia (where agricultural employment grew at the rate of $1.8 \%$ and NARE at $1 \%$ ) and Uruguay, where both went down but NARE did so faster.
}

economically active population in Brazil grew by almost 200,000 persons, whereas the agricultural population proper went down by nearly 250,000 , which means that over that period NARE absorbed nearly 450,000 persons. This author also notes that whereas NARE grew by $1.2 \%$ per year in the 1980 s, in the first half of the 1990s its annual growth rate was almost three times as much (3.5\%). In contrast, the agricultural economically active population, which grew in the 1980 s by nearly $1 \%$ per year, went down at the rate of $4.5 \%$ annually in the 1990 s (ibid., p. 23). As regards the occupational structure of NARE, Da Silva's results coincide with those of Klein.

In tabulations made on the basis of the 1994 household survey, Escobal (1996) shows that in the rural sector of Peru almost one-third of the days worked on primary and secondary activities are devoted to non-agricultural activities: a proportion which tends to go down in proportion to the land area available to families with less than 5 hectares and to go up as the average levels of education of the household members rise. Moreover, two-thirds of the days worked by the $8 \%$ of rural households headed by non-farmers -which undoubtedly consist of a heterogeneous mix of labourers and employees- are devoted to non-agricultural activities.

In a study based on samples of households in the reformed (ejido) sector in Mexico, de Janvry, Gordillo and Sadoulet (1997) estimated that in the case of the smallest units (less than 2 hectares), income from off-farm activities accounted for $82 \%$ of the total, with almost $48 \%$ coming from wage labour and micro-enterprises. In the bigger units, such income came to almost $45 \%$ of the total. Migration was vital for the smallest producers, since it accounted for almost a third of their total income. Comparison of the results obtained from the samples in 1994 and 1997 (i.e., with only three years' difference) showed a tendency towards an increase in the relative weight 
of non-agricultural income, especially from ownaccount work and micro-enterprises. On the basis of this information, Lanjouw (1998, p. 20) considers that, for a given size of family unit, the higher the proportion of its members engaged in non-agricultural work, the lower is the likelihood that the family will find itself in a situation of poverty.

In the case of El Salvador, the World Bank (1997) has estimated that approximately $36 \%$ of the rural economically active population is engaged in non-agricultural activities: almost double the proportion registered in the mid-1970s. In the case of women, the proportion engaged in NARE is nearly $72 \%$ (World Bank, 1997, p. 9, viii). Once again, the structure of NARE confirms the findings of Klein, since almost $30 \%$ are engaged in various manufacturing activities, $20 \%$ in construction, $23 \%$ in trade and transport, $22 \%$ in relatively unskilled services, and $5 \%$ in services of a higher level of skill. The World Bank study concludes that the least poor families in rural areas are those that have substantial access to non-agricultural employment, that access to better jobs is strongly linked with educational levels, and that the availability of infrastructural services significantly influences the supply of NARE.

For Ecuador, Lanjouw (1998) estimates that in the mid-1990s over $40 \%$ of the income of rural households came from non-agricultural activities, in which micro-enterprises played an important role, generating almost 900,000 jobs, or nearly $60 \%$ of the total rural labour force of that country. Moreover, there was a clear correlation between family income levels and the proportion of them that came from NARE, in which micro-enterprises accounted for the major part: such enterprises employed an average of 1.8 persons, and over $60 \%$ of them were located in the homes of the producers themselves (ibid., p. 16). As in the preceding cases, educational levels were a key determinant of the likelihood of operating a micro-enterprise, and access to electricity and telephone services were also important factors in determining the establishment of such units.

To sum up, then, NARE plays an important and growing role in absorbing the rural labour force; it is a means of relieving poverty that agriculture alone cannot offer; it makes it possible to stabilize income, making up for the seasonal nature of agricultural production and employment; and it makes it possible to diversify sources of income, thus reducing the effects of the risks which are inherent in agriculture. Access to better NARE options is strongly dependent on levels of education, infrastructural development (energy, roads, telephones), and sex, ${ }^{24}$ since men have access to better-paid activities than women.

\section{b) Determinants of the development of NARE}

The markets which must be taken into account when considering urban-rural linkages in general and those determining the structure and characteristics of NARE in particular are the markets for: labour, capital, products, and inputs, including the aspects relating to information and the risks involved in participating in them.

As Renkow (1998) points out, these markets delineate the "field" on which the rural-urban linkages are established. Within this field, the rules determining the location of production units are economies of scale in production, the demand structure (and related external pecuniary economies), and the costs deriving from distance; it could therefore be expected that the scale of production of non-agricultural enterprises will be lower in proportion to their economic distance from the major urban centres, which includes both their physical distance and the range of market-negotiated transaction costs mentioned earlier.

A recent study by Reardon (1998) analyses the determinants of the level and composition of NARE through a series of stylized factors which correspond, broadly speaking, to the conditions existing in a number of developing countries and which are represented very schematically in figure 2 , although a detailed analysis of this approach is outside the scope of the present study.

\section{The urban-rural linkage approach}

No-one questions the fact that hyper-urbanization has undesirable implications and that it is right to further the application of strategies to reduce it or at least slow down its growth. If we accept the hypothesis that urban development stimulates rural development, or can do so in certain circumstances, however, what we should do is make a critical appraisal of whether the present urban settlement pattern does indeed help

\footnotetext{
24 In connection with the question of poverty, it may also be noted that better education for women and their access to possibilities of NARE reduce fertility levels, thus bringing actual fertility closer to the desired levels.
} 
FIGURE 2

\section{Determinants of investments with rural linkages}

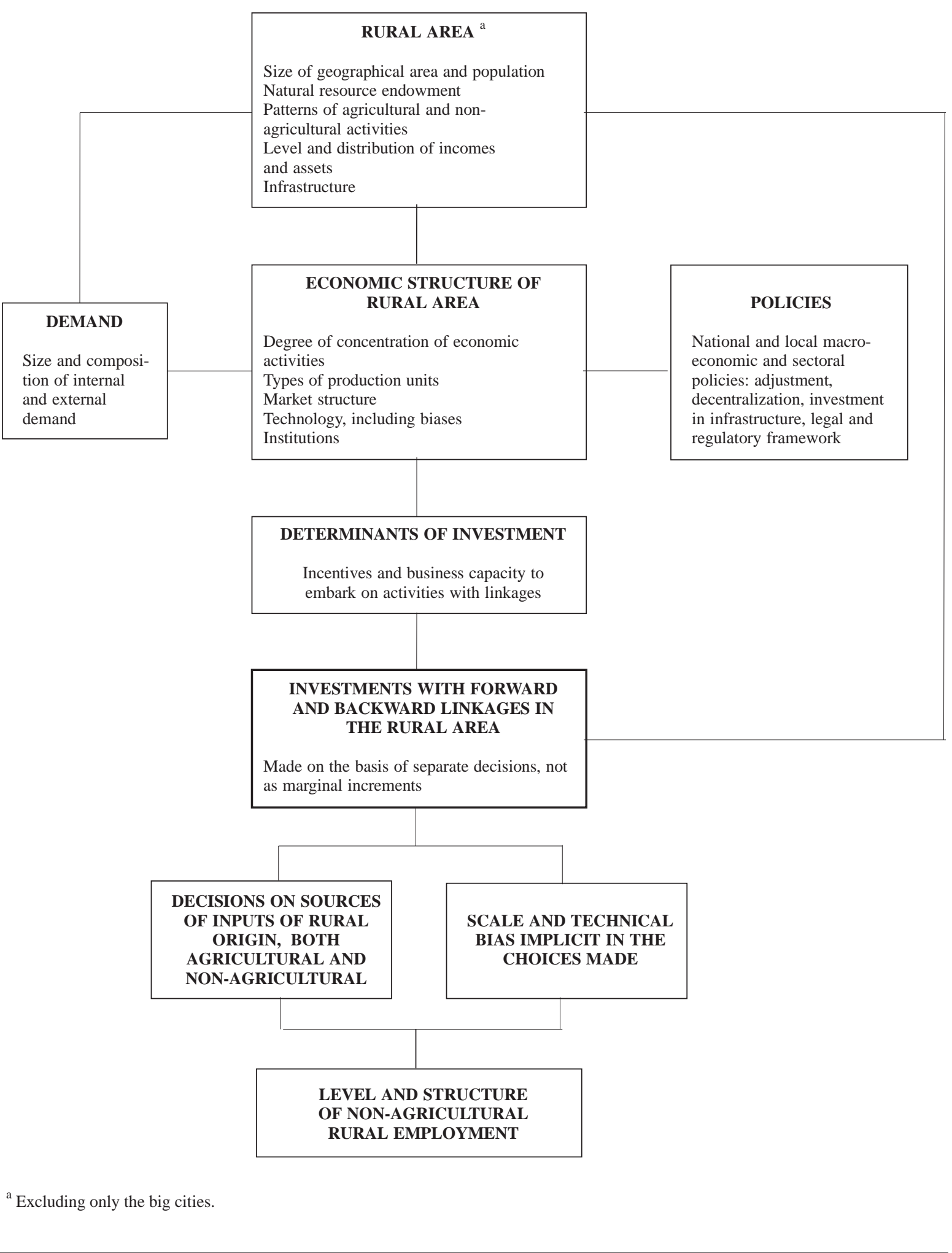

URBAN DIMENSIONS IN RURAL DEVELOPMENT • ALEXANDER SCHEJTMAN 
to promote such development ${ }^{25}$ or, in a positive sense, what measures should be promoted in order to make the potential beneficial effects materialize.

Rethinking the problems of rural development means putting them in the context of the development situation of the local economies, that is to say, placing emphasis on the economic linkages between the urban communities and their agricultural hinterland and analysing the way the different markets, fragmentary or not, fit in with each other at that level. Only in this way is it possible to tackle the questions of changing production patterns, poverty and the environment with the degree of detail needed to ensure the efficacy and participation within a given institutional framework referred to later in this article.

This type of approach may be expected to achieve: i) an understanding that the local economy operates as a set of interlinked markets and an awareness of its flaws, missing elements, and the formal and informal means of filling those gaps; ii) the formulation, on the basis of that understanding, of policies that will foster virtuous circles of reciprocal demand between the urban areas and their agricultural hinterland in a broad range of activities; iii) the identification and correction of the bottlenecks that exist in the productiondistribution chains, or the absence of vital links that could be made good through specific incentives, and iv) the promotion of local-level chains of institutions which are functional to the development of those virtuous circles, breaking away from the compartmentalization typical of public sector organization in order to take advantage of synergies in the fields of infrastructure, transfer of technology, health, education, housing and micro-enterprises.

\section{IV}

\section{Institutional innovation, decentralization and participation}

The structural heterogeneity of agriculture, the nature of rural markets, the differences between the different rural areas in terms of potential and constraints, and the special features of their links with different types of urban areas call for the application of a territorial approach to rural development. This means furthering institutional changes that will increase the efficacy of public action in this connection and taking measures designed to take account more precisely of the differences in potential, demands and constraints that can only be perceived at the local level. ${ }^{26}$

\footnotetext{
${ }^{25}$ Referring to Peru, Vergara (1992, p. 186) notes in this respect: "in reality, the most disastrous feature of migration in the region was that the peasants of the Sierra did not migrate to cities in their own region, but migrated instead to the coastal cities. As a result, the modernizing effect of urbanization was monopolized by the coastal areas. Location rents favoured the peasants of the coast and not those of the Sierra; services were provided for coastal dwellers and not those living in the Sierra, and the modernization of mentalities, of the social relations of production and of technology by-passed the Andean areas. Without cities, the Andean area vegetated in the past."

${ }^{26}$ By "institutions" we mean not only those connected with the public sector but the whole set of rules of behaviour that mould and shape social interaction. This concept includes both formal rules (laws, regulations, contracts) and those of an informal nature (customs, shared values, tacit conventions). The common
}

The processes of decentralization and deconcentration of resources, which have become part of the policies of most of the countries in the region, ${ }^{27}$ represent a first step towards the necessary institutional changes, but in many cases the compartmentalized nature of public functions at the central level tends to be reproduced also at the municipal level, with the aggravating feature that the levels of training of the technical teams are not usually high enough to ensure that they can increase the efficiency and efficacy with which the greater public resources placed at their disposal are used. ${ }^{28}$ 
Such compartmentalization and the insufficient technical level are both obstacles to fully exploiting the potential offered by the establishment of stronger links between medium-sized cities and their agricultural hinterland.

\section{Development of local institutions}

Strengthening the management capacity of the local authorities in order to further a policy of greater participation at the level of the local economy is the main task to be carried out in the field of the development of institutions, because at the local level: i) the special nature of the development needs, constraints and potential of the area can be seen much more clearly; ii) the possibilities of turning the organized participation of the population in question into a "resource" or "social capital" requires "small territorial areas and institutional interlocutors who are very close" (Borja, 1987, p. 56), and iii) it is much more feasible to make possible social control (for sustaining or redirecting policies) by those at whom public actions are aimed.

The creation of suitable conditions for participative management depends on three interrelated components: changes in the organization of the public machinery in order to strengthen urban-rural links; stimulation of the development and strengthening of the organization of the inhabitants of the urban area and its hinterland who are to be benefitted by such policies; and the need to provide the new form of organization with the means to permit the interaction of the different levels of public agents, both with each other and with the organizations representing the local population.

Within the population, the establishment and strengthening of homogeneous and representative local-level organizations should be promoted. The organizations should be homogeneous in the sense that the interests behind them and the problems they tackle are reasonably similar, in order to avoid spurious forms of representation.

With regard to the public machinery, efforts should be made to ensure sustained advances in the processes of decentralization of public management, deconcentration of human, material and financial resources, local-level integration of functions (usually dispersed and fragmented) offering potential synergies, and training of local public officials.
With regard to equipment, once the organizational bases have been laid, ${ }^{29}$ it is necessary to progress in the provision of the resources needed to establish an interactive information/communication network to link each locality with the municipality, to link the latter with the region, and to link the region with the administrative centre. This will make it possible to take advantage of information technology -a term referring to the integration of microelectronics with telecommunications and computers-, whose cost has gone down dramatically in recent decades. ${ }^{30}$ It may be noted that a number of countries have already begun to use the Internet as a rural development tool (see FAO, 1997).

\section{The new institutional structure and the local economy}

Understanding the potential and constraints of the local economy and the demands and capabilities of its population in an institutional context like the one in question will make it possible, among other things:

i) to tackle the problems of poverty, food insecurity and local environmental deterioration with a more exact knowledge of the nature of the most pressing needs and the most critical constraints;

ii) to generate and mobilize local saving in order to channel it towards local projects; ${ }^{31}$

iii) to generate projects for investment in production and social infrastructure to break bottlenecks that are hindering the formation of virtuous urban-rural circles;

iv) to integrate fragmented markets, by strengthening the regional market networks, especially wholesale markets, and thus simplifying the process of bringing together buyers and sellers in the same place and reducing transaction costs (UNDP/UNCHS, 1995);

\footnotetext{
${ }^{29}$ Even though these bases may be of an embryonic nature, they should be made sufficiently flexible to permit their subsequent modification in the light of experience.

${ }^{30}$ The cost of information processing and computing capacity has gone down by a steady $30 \%$ per year in real terms during the last three decades. In contrast, the cost of one of the goods most affected by technical progress in the first industrial revolution -cotton textiles- went down by approximately $3.4 \%$ per year from the late 18th century to the early 19th century (OECD, 1988, p. 37).

${ }^{31}$ In many countries of the region, remittances from former local residents who have gone to work elsewhere or even abroad are a by no means insignificant source of resources which could be channeled into local saving systems.
} 
v) to take more specific account of the nature of the needs in respect of training and technological progress both in agriculture and among local small-scale industry, which is often only at an incipient stage;

vi) to give access to information, especially that which helps to improve strategies for obtaining employment and income, since the absence of information, or shortcomings in it, increase the danger of faulty resource allocation or of missing or overlooking existing opportunities. This aspect is particularly important in view of the considerable weight of work away from the farm in the family economy;

vii) to satisfy specific demands regarding environmental problems affecting the locality; and

viii) to form a suitable space for the participation of society at large and for the public agents to render accounts to the population they serve.

Although it is generally considered that the above advantages are perfectly reasonable, there are no generally applicable proposals on how to generate processes of institutional change which will secure the desired effects in each particular case. There does seem to be general agreement among the various authors regarding some of the basic conditions that need to be met if the decentralization process is to live up to expectations. Among these conditions are the existence of democratically elected authorities, a society with representative organizations, and transparency in public management which obviates clientage, corruption and rent-seeking. Although the whole set of these conditions is unlikely to be satisfied in absolute terms, there is nevertheless no doubt that the further the actual conditions of each country are from them, the less likely it is that decentralization -if adopted- will fulfil the objectives of rural development.

In general, paradoxical though this may seem, in the present phase of the democratic development of many Latin American countries the central government plays a key role in decentralization. This is not only because in order to achieve this objective the government must naturally delegate some of its authority to subnational bodies and grass-roots organizations, but also because it must, in addition, obviate the misuse of funds, avoid the fixing of priorities by a handful of powerful interests, and prevent funds from being squandered on pointless initia- tives by inexpert or corrupt local officials. ${ }^{32}$ Sometimes, the central government must pressure the local levels of government through its subnational bodies to set in motion processes of real participative decentralization, as noted in the case studies analysed by Tendler: "In so far as the Ceará cases involved decentralization, they revealed something very different from the processes of the unidirectional transfer of authority from the central to the local level depicted in the typical stylized versions of decentralization. Surprisingly, the central government took away authority from the local level even though, ultimately, its actions helped to strengthen local authority" (Tendler, 1997, pp. 146-147).

\section{Absence of pre-established ways of decentralization}

Finally, we will refer to the difficulty of laying down general rules that will make it more or less feasible to generate decentralized and participative structures. De Benedicty ${ }^{33}$ rightly noted that in spite of the growing recognition in the economic literature of the importance of institutions, the results of the studies made in this respect have not progressed beyond the analytical level -how certain institutions arose and their economic and social impact- to the normative level of determining, for a given situation, the specific forms of the institutional matrix which will ensure the achievement of given economic and social objectives.

In other words, it is not possible to determine $a$ priori the mechanism whereby a satisfactory decentralization process can be generated and developed, or the extent to which authority should be delegated or not in such areas as the imposition and collection of taxes, autonomy in expenditure, locally decided investments and projects, regulations regarding the

\footnotetext{
${ }^{32}$ Hommes (1995, p. 337) notes that the Colombian Constitution lays down that a portion of current revenue must be allocated to the departments and that the latter must share a percentage of these resources with the municipalities. The use of these funds is regulated by law, with fixed percentages being assigned to the different functions. Some critics hold that the controls under this system are excessive in that they limit decentralization, but the rigidity of the controls can, however, obviate misuse of funds and prevent them from being squandered on pointless initiatives by inexpert or corrupt local officials.

33 In a manuscript comment on a preliminary version of this paper.
} 
environment, trade and transport, etc. ${ }^{34}$ It comes as no surprise that, among the conclusions of a recent Consultatory Meeting on Decentralization it was noted that in so far as decentralization depends on many national and local factors, such as the legal framework, the political system, the density of civil society, the degree of national cohesiveness, etc., there is no single way to decentralization, so that it is necessary to be on one's guard against simplistic models and excessively categorical predictions on the ways to decentralization and its subsequent effects. ${ }^{35}$

Notwithstanding the foregoing, the greater or lesser feasibility of a participative decentralization process for a given area or region would appear to depend on the degree of concentration of the habitat, the degree of homogeneity of the social groups, their levels of organization, and the quality and coverage of the infrastructure. Generally speaking, this process will be more viable in concentrated habitats with a relatively homogeneous and organized population and a reasonable level of local infrastructure, while it will run into serious difficulties -if indeed it manages to function at all- in dispersed habitats with a heterogeneous population, lacking both organization and infrastructure.

(Original: Spanish)

\section{Bibliography}

Belsky, E. and G. Karaska (1990): Approaches in locating urban functions in developing rural areas, International Regional Science Review, No. 13, Morgantown, West Virginia, West Virginia University, Regional Research Institute.

Bardhan, P. (ed.) (1991): The Economic Theory of Agrarian Institutions, Clarendon Paperbacks, Oxford University Press.

Bhadra, D. and A. Salazar Brandao (1993): Urbanization, Agricultural Development and Land Allocation, World Bank discussion papers, No. 201, Washington, D.C., World Bank.

Borja, J. (1987): Descentralización del Estado, movimientos sociales y gestión local, Santiago, Chile, Ibero-American Co-operation Institute (ICI)/Latin American Faculty of Social Sciences (FLACSO).

Cruz, M. E. (1997): Llay Llay: Una ciudad intermedia del Chile Central. (consultant's report), Santiago, Chile, Food and Agriculture Organization of the United Nations (FAO), mimeo.

Da Silva, J. G. (1998): Novo rural brasileiro, São Paulo, Brazil, State University at Campinas, Instituto de Economía, mimeo.

\footnotetext{
${ }^{34}$ See, in this respect, the critical analysis of fiscal decentralization by Prud'homme and the respective articles by Prud'homme, Tanzi, Oates and Hommes in World Bank, 1995.

35 The case studies analysed by Tendler (1997) show the limitations of simplistic approaches which assume that decentralization and participation are mutually and necessarily reciprocal and clearly reveal the need to question some assumptions about the central government, society at large and non-governmental organizations, while at the same time suggesting the need for a three-way approach (local, central and civic) instead of the oneway approach of conventional proposals.
}

de Janvry, A. and P. Glikman (1991): Encadenamientos de producción en la economía campesina en el Ecuador, San José, Costa Rica, International Fund for Agricultural Development (IFAD)/Instituto Interamericano de Cooperación para la Agricultura (IICA), September.

de Janvry, A., G. Gordillo and E. Sadoulet (1997): Mexico's Second Agrarian Reform, La Jolla, San Diego, University of California, Center for U.S.Mexican Studies.

ECLAC (Economic Commission for Latin America and the Caribbean) (1982): Economía campesina y agricultura empresarial (tipología de productores del agro mexicano), Mexico City, Siglo Veintiuno Editores, S.A.

(1990): Changing Production Patterns with Social Equity, LC/G.1601-P, Santiago, Chile. United Nations publication, Sales No. E.90.II.G.6.

-(1992): Social Equity and Changing Production Patterns: An Integrated Approach, LC/G.1701 (SES.23/3), Santiago, Chile, 6 February. United Nations publication, Sales No. E.92.II.G.5.

- (1996a): Agroindustria y pequeña agricultura: síntesis comparativa de distintas experiencias, Santiago, Chile.

- (1996b): Pequeña agricultura y agroindustria en el Perú, Santiago, Chile.

(1998): Social Panorama of Latin America 1997, LC/G.1982-P, Santiago, Chile.

Escobal, J. (1996): Diferenciación campesina y políticas diferenciadas, paper presented at the Taller Latinoamericano de Políticas Diferenciadas y Tipologías Agrarias, Santiago, Chile, 20-24 May.

Evans, H. E. (1992): A virtuous circle model of ruralurban development: Evidence from Kenya, The Journal of Development Studies, vol. 28, No. 4, London, Frank Cass \& Co. Ltd. 
Fajnzylber, F. (1991): International insertion and institutional renewal, CEPAL Review, No. 44, LC/G.1667-P, Santiago, Chile, ECLAC.

Fajnzylber, F. and A. Schejtman (1995): Agricultura, industria y transformación productiva. América Latina a fines de siglo, Mexico City, Fondo de Cultura Económica (FCE).

FAO (United Nations Food and Agriculture Organization) (1997): Internet y el desarrollo rural y agrícola: un enfoque integrado, Rome, Sustainable Development Department, mimeo.

Figueroa, A. (1981): La economía campesina de la Sierra del Perú, Lima, Pontificia Universidad Católica del Perú.

- (1998): Pobreza rural en los países andinos, in L. Reca and R. Echeverría (eds.), Agricultura, medio ambiente y pobreza rural en América Latina, Washington, D. C., International Food Policy Research Institute (IFPRI)/Inter-American Development Bank (IDB).

Franco, C. (1992): La investigación agraria: argumentando un reproche, Debate agrario, No. 13, Lima, Centro Peruano de Estudios Sociales (CEPES).

Hansen, N. (1990): Impacts of small and intermediatesized cities on population distribution: Issues and responses, Regional Development Dialogue, vol. 11, No. 1, Nagoya, Japan, United Nations Centre for Regional Development.

Hirshman, A. O. (1961): La estrategia del desarrollo económico, Mexico City, Fondo de Cultura Económica (FCE).

Hommes, R. (1995): Conflicts and dilemmas of decentralization, Annual World Bank Conference on Development Economics 1995, Washington, D. C., World Bank.

International Regional Science Review (1992a): vol. 14, Morgantown, West Virginia, West Virginia University, Regional Research Institute.

- (1992b): vol. 15, Morgantown, West Virginia, West Virginia University, Regional Research Institute.

Jacobs, J. (1970): The Economy of Cities, London, Random House.

Jeffrey, H. and others (1989): Environment and the poor: Development strategies for a common agenda, U.S.Third World Policy Perspectives, No. 11, Washington, D. C., Overseas Development Council (ODC).

Jones, E. L. and S. J. Wolf (1969): Agrarian Change and Economic Development, London, Methuen \& Co. Ltd.

Johnston, B. and P. Kilby (1975): Agriculture and Structural Transformation: Economic Strategies in Late Developed Countries, London, Oxford University Press.
Katzman, M. (1974): The Von Thünen paradigm, the industrial-urban hypothesis and the spatial structure of agriculture, American Journal of Agricultural Economics, vol. 56, pp. 663-696, San Francisco, California, American Agriculture Economic Association (AAEA).

Klein, E. (1992): El empleo rural no agrícola en América Latina, Investigaciones sobre empleo, No. 364, Santiago, Chile, Regional Employment Programme for Latin America and the Caribbean (PREALC).

Krugman, P. (1997): Development, Geography and Economic Theory, Cambridge, Massachusetts, The MIT Press.

Lanjouw, P. (1998): Rural non-farm employment and poverty: Evidence from household survey data in Latin America, paper presented at the IFPRI Workshop on Strategies for Stimulating Growth of the Rural NonFarm Economy, Washington, D. C., International Food Policy Research Institute.

Lipton, M. (1968): The theory of the optimizing peasant, The Journal of Development Studies, vol. 4, No. 3, London, Frank Cass \& Co. Ltd.

(1980): Migration from rural areas of poor countries: the impact on rural productivity and income distribution, World Development, vol. 18, pp. 1-24.

Mertins, G. (1995): La diferenciación socio-espacial y funcional de las ciudades intermedias latinoamericanas: ejemplos del noroeste argentino, Revista interamericana de planificación, vol. 28, No. 112, Cuenca, Ecuador.

Myrdal, G. (1962): Teoría económica y regiones subdesarrolladas, Mexico City, Fondo de Cultura Económica.

Oates, W.E. (1995): Comments on "Conflicts and dilemmas of decentralization" by Rudolph Hommes, Annual World Bank Conference on Development Economics 1995, Washington, D. C., World Bank.

OECD (Organization for Economic Co-operation and Development) (1988): New Technologies in the 1990's. A Socio-Economic Strategy, Paris.

Ortega,L. (1998): Desarrollo rural articulado a ciudades intermedias (consultant's report) El Salvador, UNDP, mimeo.

Paniagua, A. (1994): Desarrollo agrícola asociado a ciudades intermedias en agroindustria y pequeña agricultura, La Paz, FAO/Latin American Institute for Social Research (ILDIS).

-(1997): Análisis complementario del proyecto de desarrollo del corredor Puno-Cusco, (consultant's report), Lima, Corporación Financiera de Desarrollo, mimeo.

Pearse, A. (1984): Seeds of Plenty, Seeds of Want, Geneva, United Nations Research Institute for Social Development (UNRISD). 
Prud'homme, R. (1995): Comments on "Conflicts and dilemmas of decentralization" by Rudolph Hommes, Annual World Bank Conference on Development Economics 1995, Washington, D. C., World Bank.

Reardon, T. (1998): Agroindustrialization in intermediate cities in Latin America: hypotheses regarding employment effects on the rural poor, paper presented at the IFPRI Workshop on Strategies for Stimulating Growth of the Rural Non-Farm Economy, Washington, D. C., International Food Policy Research Institute (IFPRI).

Renkow, M. (1998): Cities, Towns and the Rural NonFarm Economy, paper presented at the IFPRI Workshop on Strategies for Stimulating Growth of the Rural Non-Farm Economy, Washington, D. C., International Food Policy Research Institute (IFPRI).

Riordan, J. (1997): Elementos para el desarrollo de las ciudades intermedias en apoyo a la lucha contra la pobreza extrema, Lima, Peru, Ministerio de la Presidencia, mimeo.

Rondinelli, D. (1990): Locational planning and regional economic development: Appropriate methods in developing countries, International Regional Science Review, No. 13, Morgantown, West Virginia, West Virginia University, Regional Research Institute.

Sadoulet, E. and A. de Janvry (1995): Quantitative Development Policy Analysis, Baltimore, Maryland, Johns Hopkins University Press.

Schejtman, A. (1980): The peasant economy: internal logic, articulation and persistence, CEPAL Review, No. 11, Santiago, Chile, ECLAC. United Nations publication, Sales No. E.80.II.G.3.

(1997): Peasants and structural adjustment in Latin America, in S. Lindberg and A. Sverrisson (eds.), Social Movements in Development: The Chal- lenge of Globalization and Democratization, London, Macmillan Press Ltd.

- (1998): Agroindustria y pequeña agricultura. Experiencias y opciones de transformación, in ECLAC/German Agency for Technical Cooperation (GTZ)/FAO, Agroindustria y pequeña agricultura: vínculos, potencialidades y oportunidades comerciales, Santiago, Chile.

Schultz, T. (1953): The Economic Organization of Agriculture, New York, McGraw Hill.

Tanzi, V. (1995): Fiscal federalism and decentralization: A review of some efficiency and macroeconomic aspects, Annual World Bank Conference on Development Economics 1995, Washington, D. C., World Bank.

Tendler, J. (1997): Good Government in the Tropics, Baltimore, Maryland, Johns Hopkins University Press.

UNDP/UNCHS (United Nations Development Programme/ United Nations Conference on Human Settlements Habitat) (1995): Rural-urban linkages: Policy guidelines for rural development, Rome, mimeo.

Vergara, R. (1992): La ciudad y el campo ¿una danza eterna?, Debate agrario, No. 13, Lima, CEPES.

Von Haldenwang, C. (1997): Descentralización, fases de ajuste y legitimación, Diálogo científico, vol. 6, No. 2, Tübingen, Germany, Instituto de Colaboración Científica.

World Bank (1995): Annual World Bank Conference on Development Economics 1995, Washington, D. C.

- (1997): El Salvador Rural Development Study. Main Report, vol. 2, Washington, D. C.

Yifu, J. and J. Nugent (1995): Institutions and economic development, in J. Behrman y T. N. Srivanasan (eds.), Handbook of Development Economics, vol. 3, Amsterdam, Elsevier Science Publishers B. V. 